\title{
1-methylcyclopropene prolongs the vase life of roses cv. Osiana
}

\author{
Delaine Cristina Cordeiro ${ }^{1} \oplus$, Ariana Mota Pereira ${ }^{2} \oplus$, Kharen Priscilla de Oliveira Salomão Petrucci² ${ }^{\circledR}$, \\ Fernando Luiz Finger ${ }^{2} \mathbb{0}$ \\ ${ }^{1}$ Centro Tecnológico de Desenvolvimento Regional de Viçosa, Parque Tecnológico de Viçosa, Viçosa-MG, Brasil. E-mail: delaineccordeiro@gmail.com
${ }^{2}$ Universidade Federal de Viçosa, Viçosa-MG, Brasil. E-mail: ariana.mota@ufv.br; kharen.salomao@ufv.br; ffinger@ufv.br
}

ABSTRACT: The objective of this study was to determine the effect of 1-methylcyclopropene (1-MCP) on vase life of rose cv. Osiana in different storage conditions and in the presence of exogenous ethylene. The roses were treated with $0.5 ; 1.0 ; 1.5$ and $2.0 \mathrm{~g} \mathrm{~m}^{-3}$ of Ethylbloc ${ }^{\circledR}$, and submitted to the following conditions: Storage at $5^{\circ} \mathrm{C}$ with stems in water; Storage at $22^{\circ} \mathrm{C}$ with stems in water; Storage at $5{ }^{\circ} \mathrm{C}$ in 'Strong' type paper for 3 days and subsequent storage at $22{ }^{\circ} \mathrm{C}$. The best storage condition was at $22{ }^{\circ} \mathrm{C}$ with the stems in the water. Doses greater than $1.0 \mathrm{~g} \mathrm{~m}-3$ of Ethylbloc ${ }^{\circledR}$ prolonged vase life. In this condition, the stems were treated with $1.0 \mathrm{~g} \mathrm{~m}^{3}{ }^{3}$ thylbloc $^{\circledR} ; 1.0 \mathrm{~g} \mathrm{~m}^{-3}$ Ethylbloc $^{\circledR}+10 \mu \mathrm{L} \mathrm{L}^{-1}$ ethylene and $10 \mu \mathrm{L} \mathrm{L}^{-1}$ ethylene for $24 \mathrm{~h}$. The Ethylbloc ${ }^{\circledR}$ increased vase life even in the presence of ethylene and fresh mass on the first two days. It reduced ethylene production by flowers in the first $24 \mathrm{~h}$, and respiratory activity after $36 \mathrm{~h}$. It can be concluded that the concentration of $1.0 \mathrm{~g} \mathrm{~m}^{-3}$ of Ethylbloc ${ }^{\circledR}$ prolongs the vase life of $\mathrm{cv}$. Osiana stored at room temperature with the stems in water even in the presence of exogenous ethylene.

Key words: ethylene; inhibitors; post-harvest; respiration; rose $\times$ hybrida

\section{1-metilciclopropeno prolonga a vida de vaso de rosas cv. Osiana}

RESUMO: Objetivou-se com este estudo determinar o efeito do 1-metilciclopropeno (1-MCP) na vida de vaso da rosa cv. Osiana em diferentes condições de armazenamento e na presença de etileno exógeno. As rosas foram tratadas com 0,5; 1,0; 1,5 e $2,0 \mathrm{~g} \mathrm{~m}^{-3}$ de Ethylbloc ${ }^{\circledR}$ e submetidas às condições: Armazenamento a $5^{\circ} \mathrm{C}$ com as hastes na água; Armazenamento a $22^{\circ} \mathrm{C}$ com as hastes na água; Armazenamento a $5^{\circ} \mathrm{C}$ em papel tipo 'Strong' por 3 dias e posterior armazenamento a 22 ${ }^{\circ} \mathrm{C}$. A melhor condição de armazenamento foi a $22{ }^{\circ} \mathrm{C}$ com as hastes na água. As dosagens acima de $1,0 \mathrm{~g} \mathrm{~m}^{-3} \mathrm{de} \mathrm{Ethylbloc}^{\circledR}$ prolongou a vida de vaso. Nesta condição, as hastes foram tratadas com $1.0 \mathrm{~g} \mathrm{~m}^{-1}$ Ethylbloc $^{\circledR} ; 1.0 \mathrm{~g} \mathrm{~m}^{-3} \mathrm{Ethylbloc}^{\circledR}+10 \mu \mathrm{L} \mathrm{L}^{-1}$ etileno e $10 \mu \mathrm{L} \mathrm{L}^{-1}$ etileno por $24 \mathrm{~h}$. O Ethylbloc ${ }^{\circledR}$ aumentou a vida de vaso mesmo na presença de etileno, aumentando a massa fresca nos primeiros dois dias, reduzindo a produção de etileno pelas flores nas primeiras $24 \mathrm{~h}$ e a atividade respiratória a partir das $36 \mathrm{~h}$. Conclui-se que a concentração de $1,0 \mathrm{~g} \mathrm{~m}^{-3}$ de Ethylbloc ${ }^{\circledR}$ prolonga a vida de vaso das rosas cv. Osiana armazenadas a temperatura ambiente com as hastes em água mesmo na presença de etileno exógeno.

Palavras-chave: etileno; inibidores; pós-colheita; respiração; rosa x hibrida 


\section{Introduction}

During transport and storage the flowers are subjected to stress conditions such as low light intensity, mechanical damage, disease incidence, high temperature and water stress, which lead to increased endogenous ethylene production (Finger et al., 2015), considered in species sensitive, such as 'Osiana' rose, the main cause of the reduction of vase life by causing abscission, discoloration and cervical folding (In et al., 2017).

Thus, to maintain quality for a longer period of time, it is necessary to adopt measures that reduce the effects of exposure to ethylene, such as the application of inhibitors of the synthesis or action of hormone. The commercial substance 1-methylcyclopropene (1-MCP) has been shown to be most effective in blocking the action of ethylene on climacteric and non-climacteric fruits, green leafy vegetables and some species of ornamental plants (Finger et al., 2015) by suppressing genes such as ETR, CTR, ERS and ACO (Cheema et al., 2013) blocking the binding of ethylene to the receptor.

However, new ethylene receptors are constantly formed, which makes the efficiency of 1-MCP dependent on exposure time, 1-MCP concentration used and ethylene concentration in the transport and storage environment. Additionally, its effect is depends on the variety and cultivar. In Phalaenopsis (Chang et al., 2013) and Tropaeolum majus (Silva \& Finger, 2015) 1-MCP application prolonged vase life in the presence and absence of ethylene. In 'Calypso' and 'MG 302' Pepper, the application of 1-MCP did not block all ethylene receptors and, when applied ethylene, caused leaf abscission (Lima et al., 2017). Therefore, the objective of this study was to determine the effect of 1-methylcyclopropene (1-MCP) on the vase life of rose cv. Osiana in different storage conditions and in the presence of exogenous ethylene.

\section{Material and Methods}

Floral stems of rose cv. Osiana were obtained from a commercial garden in Barbacena, state of Minas Gerais $\left(21^{\circ} 13^{\prime} 33^{\prime \prime} \mathrm{S}, 43^{\circ} 46^{\prime} 25^{\prime \prime}\right.$ ' W with an altitude of $\left.1160 \mathrm{~m}\right)$. The floral buds were harvested in the morning at the commercial stage, with all their sepals open and closed petals (Cordeiro et al., 2011).The stems were standardized at $50 \mathrm{~cm}$ and then cutting were performed in water.In the first experiment, the flower stems were placed in water, conditioned in $0.103-\mathrm{m}^{3}$ airtight chambers and treated with $0.5 ; 1.0 ; 1.5$ and $2.0 \mathrm{~g} \mathrm{~m}^{-3}$ Ethylbloc $^{\circledR}(0.14 \%$ 1-MCP - 1-MCP was released by adding water at $40{ }^{\circ} \mathrm{C}$ ) at $22{ }^{\circ} \mathrm{C}$ for $24 \mathrm{~h}$. Control stems were not treated with Ethylbloc ${ }^{\circledR}$ remaining in distilled water a $22{ }^{\circ} \mathrm{C}$.

Subsequently, the treated flowers were transferred to three conditions: Condition 1: Storage at $22^{\circ} \mathrm{C}$ with the base of the rods in the water; Condition 2: Conditioning at $5{ }^{\circ} \mathrm{C}$ with the base of the stems in the water for 7 days and subsequent storage at $22{ }^{\circ} \mathrm{C}$; Condition 3: Conditioning at $5{ }^{\circ} \mathrm{C}$ on 'Strong' type waxed paper for 3 days and subsequent storage at $22^{\circ} \mathrm{C}$. All stems remained constantly under fluorescent white light of $10 \mu \mathrm{mol} \mathrm{m} \mathrm{m}^{2} \mathrm{~s}^{-1}$, in which the base of the stems were cut every two days inside containers with water. The vase life of the flower stems was evaluated.

Regarding the second experiment, the treatments were, as follows: $1.0 \mathrm{~g} \mathrm{~m}^{-3}$ Ethylbloc $^{\circledR}$ for $24 \mathrm{~h} ; 1.0 \mathrm{~g} \mathrm{~m}^{-3}$ Ethylbloc $^{\circledR}$ $+10 \mu \mathrm{L} \mathrm{L}^{-1}$ ethylene for $24 \mathrm{~h}$ and $10 \mu \mathrm{L} \mathrm{L}^{-1}$ ethylene for $24 \mathrm{~h}$. Afterwards, the flowers were kept in pots with distilled water at $22{ }^{\circ} \mathrm{C}$. Control stems were not treated with Ethylbloc ${ }^{\circledR}$ nor ethylene remaining in distilled water at $22{ }^{\circ} \mathrm{C}$. All stems remained constantly under fluorescent white light of $10 \mu \mathrm{mol}$ $\mathrm{m}^{2} \mathrm{~s}^{-1}$. Ethylene and the exposure time used were those due to previous studies described by Cordeiro et al. (2011). The fresh mass variation, vase life, ethylene and $\mathrm{CO}_{2}$ production by flowers were evaluated.

The Vase life was determined visually following the protocol determined by Cordeiro et al. (2011). The fresh mass variation of the stems was determined daily by the difference of weight of the stems, considering the initial weight as $100 \%$.

Ethylene and $\mathrm{CO}_{2}$ were determined every $12 \mathrm{~h}$ by gas chromatography (GC-14B Shimadzu Corp., Kyoto, Japan). The flower stems were placed in containers filled with water and placed in airtight sealing chambers at $0.015 \mathrm{~m}^{3}$ at $22{ }^{\circ} \mathrm{C}$. For determination of ethylene, $\mathrm{NaOH}$ was placed in the chambers to avoid $\mathrm{CO}_{2}$ accumulation (Mapeli et al., 2011). Carbon dioxide and ethylene were separated in a column Porapak- $Q$ at $60^{\circ} \mathrm{C}$ using a GC-14B (Shimadzu, Japan) equipped with a thermal conductivity and flame ionization detector.

The experiment was conducted in a completely randomized design, with four replicates containing five flowers in each. Data were submitted to analysis of variance and vase life means were compared by the test of Tukey at $p$ $>0.05$ probability. Data on variation of fresh mass, ethylene and $\mathrm{CO}_{2}$ production were presented by descriptive statistics.

\section{Results and Discussion}

When the flower stems were conserved at $22{ }^{\circ} \mathrm{C}$ with the base of the stems in water, doses of 1.0, 1.5 and $2.0 \mathrm{gm}^{-3}$ Ethylbloc ${ }^{\circledR}$ increased vase life by 1 and 2 days, in comparison to control flowers and treated with $0.5 \mathrm{gm}^{-3}$ Ethylbloc $^{\circledR}$, respectively (Table 1 ). While flowers cooled at $5{ }^{\circ} \mathrm{C}$ for seven

Table 1. Vase life of 'Osiana' rose after application of $0 ; 0.5$; 1.0; 1.5 and $2.0 \mathrm{gm}^{-3}$ Ethylbloc $^{\circledR}$ and storage at $22{ }^{\circ} \mathrm{C}$ with the base of the stem in the water (T1); storage at $5{ }^{\circ} \mathrm{C}$ with the base of the stems in the water for 7 days and subsequent storage at $22{ }^{\circ} \mathrm{C}(\mathrm{T} 2)$; storage at $5{ }^{\circ} \mathrm{C}$ on 'Strong' type waxed paper for 3 days and subsequent storage at $22^{\circ} \mathrm{C}$ (T3).

\begin{tabular}{cccc}
\hline \multicolumn{5}{c}{ Vase life (days) } \\
\hline$\left(\mathrm{g} \mathrm{m}^{-3}\right.$ Ethylbloc $\left.^{\circ}\right)$ & $\mathrm{T} 1$ & $\mathrm{~T} 2$ & $\mathrm{~T} 3$ \\
\hline 0 & $5.5 \mathrm{~b}$ & $4.0 \mathrm{~b}$ & $5.7 \mathrm{a}$ \\
0.5 & $6.6 \mathrm{~b}$ & $3.7 \mathrm{~b}$ & $6.1 \mathrm{a}$ \\
1.0 & $7.6 \mathrm{a}$ & $5.6 \mathrm{a}$ & $6.7 \mathrm{a}$ \\
1.5 & $7.4 \mathrm{a}$ & $5.4 \mathrm{a}$ & $6.6 \mathrm{a}$ \\
2.0 & $7.7 \mathrm{a}$ & $5.5 \mathrm{a}$ & $6.5 \mathrm{a}$ \\
\hline
\end{tabular}

Equal letters in the same line do not differ from one another by the Tukey test at $5 \%$ probability. 
days keeping the base of the stems in water and later stored at $22{ }^{\circ} \mathrm{C}$ increased the vase life by approximately 1.4 and 1.7 days with the application of 1.0, 1.5 and $2.0 \mathrm{gm}^{-3}$ Ethylbloc $^{\circledR}$ compared to the control and $0.5 \mathrm{gm}^{-3}$ Ethylbloc $^{\circ}$ (Table 1). Refrigeration at $5{ }^{\circ} \mathrm{C}$ associated with the storage of stems in 'Strong' type paper for 3 days and subsequent storage at $22^{\circ} \mathrm{C}$ did not increase vase life with Ethylbloc ${ }^{\circledR}$ application (Table 1 ).

The storage condition of the flowers that promoted the greatest increase in vase life with the application of Ethylbloc ${ }^{\circ}$ was the one that caused the least stress on the flower stems, the storage at $22{ }^{\circ} \mathrm{C}$ with the stems in water. Refrigeration and dry conditioning of the stems were conditions of abiotic stress that led to increased ethylene production (In et al., 2017) reducing the efficiency of Ethylbloc ${ }^{\circledR}$. Thus, the doses tested or exposure time may not have been sufficient to block ethylene receptors.

The efficiency of applying the $1.0 \mathrm{gm}^{-3}$ dose of Ethylbloc ${ }^{\circ}$ to flower stems at $22^{\circ} \mathrm{C}$ with water base was maintained even in the presence of ethylene in the environment. In studies with roses cv. Sparkle was also observed efficiency of Ethylbloc ${ }^{\circ}$ application in the presence of ethylene (Ali et al., 2014). Application of $1.0 \mathrm{gm}^{-3}$ Ethylbloc ${ }^{\circledR}$ increased vase life by about 2 days compared to control (without ethylene or Ethylbloc ${ }^{\circledR}$ ) and 5 days compared to $10 \mu \mathrm{L} \mathrm{L}^{-1}$ stems exposed ethylene (Figure 1). While, exposure of flower stems to ethylene reduced vase life by 2 days compared to control (Figure 1). In a study of 33 rose cultivars, $64 \%$ had reduced vase life with exposure to ethylene (In et al., 2017).

These results show that Ethylbloc ${ }^{\circledR}$ can be used to maintain the quality of rose cv. Osiana in the presence of ethylene under storage and transport conditions with only a single application, because in many species sensitivity to ethylene is observed even after Ethylbloc ${ }^{\circledR}$ application due to the emergence of new receptors, requiring successive applications of the product. The Ethylbloc ${ }^{\circledR}$ application reduces ethylene production at DcETR1 and DcCTR1 mRNA levels, however, increasing the transcriptional level of the DcETR1 ethylene receptor results in the recovery of ethylene sensitivity (In et al., 2016).

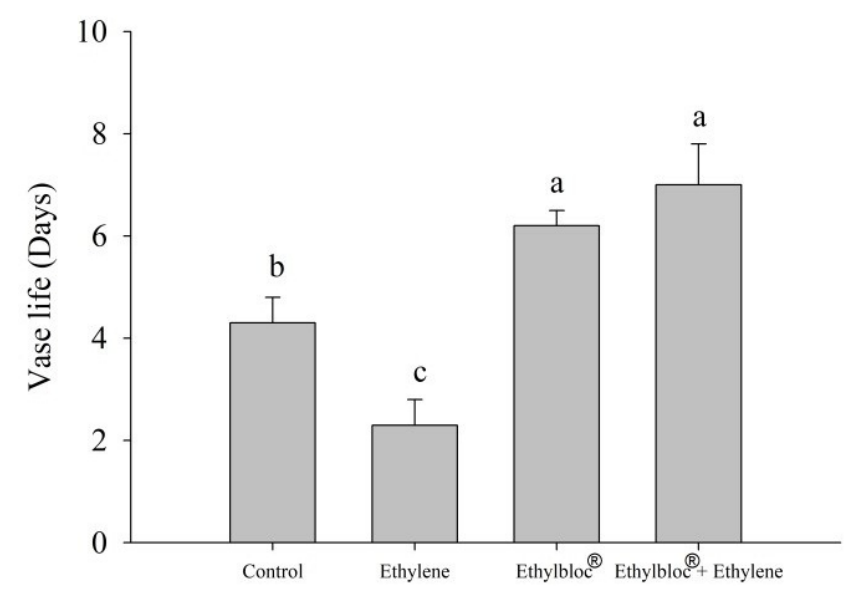

Equal letters do not differ from each other by the Tukey test at $5 \%$ probability.

Figure 1. Vase life of roses cv. Osiana of the control, treated with $10 \mu \mathrm{L} \mathrm{L}^{-1}$ etileno; $1.0 \mathrm{gm}^{-1}$ Ethylbloc $^{\circledR}$ and $1.0 \mathrm{gm}^{-3}$ Ethylbloc $^{\circledR}+10 \mu \mathrm{L} \mathrm{L}^{-1}$ etileno by $24 \mathrm{~h}$.
The prolongation of vase life with Ethylbloc ${ }^{\circledR}$ application was due to the reduction of ethylene production by the flowers, which remained below $80 \mu \mathrm{Lg}^{-1} \mathrm{~h}^{-1}$ over $48 \mathrm{~h}$ after Ethylbloc ${ }^{\circledR}$ application (Figure 2 ) and reduction of respiratory activity $24 \mathrm{~h}$ after application, remaining below $3000 \mathrm{ml} \mathrm{kg}{ }^{-1}$ $\mathrm{h}^{-1}$ (Figure 3), as respiration and production and ethylene correlate with senescence of ornamental plants (Finger et al., 2016).

The stems treated with Ethylbloc ${ }^{\circledR}$, with or without exogenous ethylene, presented a fresh mass variation by 18 $\%$, whereas the control and the flowers exposed to ethylene on the second day of storage presented a variation by $13 \%$

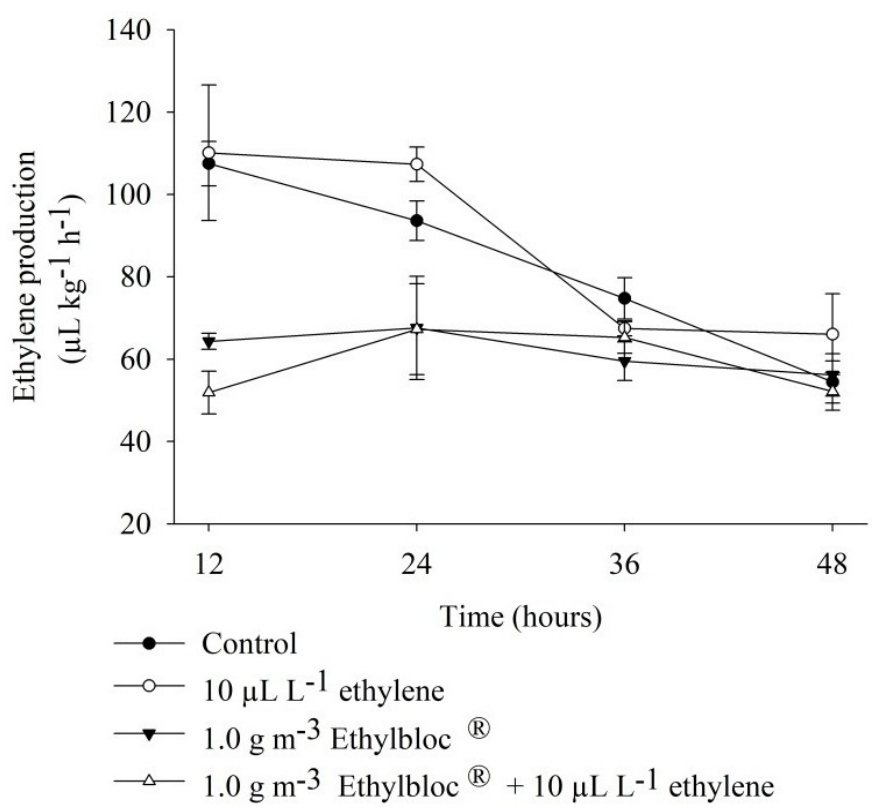

Figure 2. Production of ethylene of roses cv. Osiana of the control, treated with $10 \mu \mathrm{L} \mathrm{L}^{-1}$ etileno; $1.0 \mathrm{gm}^{-1}$ Ethylbloc $^{\circledR}$ and $1.0 \mathrm{gm}^{-3}$ Ethylbloc $^{\circledast}+10 \mu \mathrm{L} \mathrm{L}^{-1}$ etileno by $24 \mathrm{~h}$.

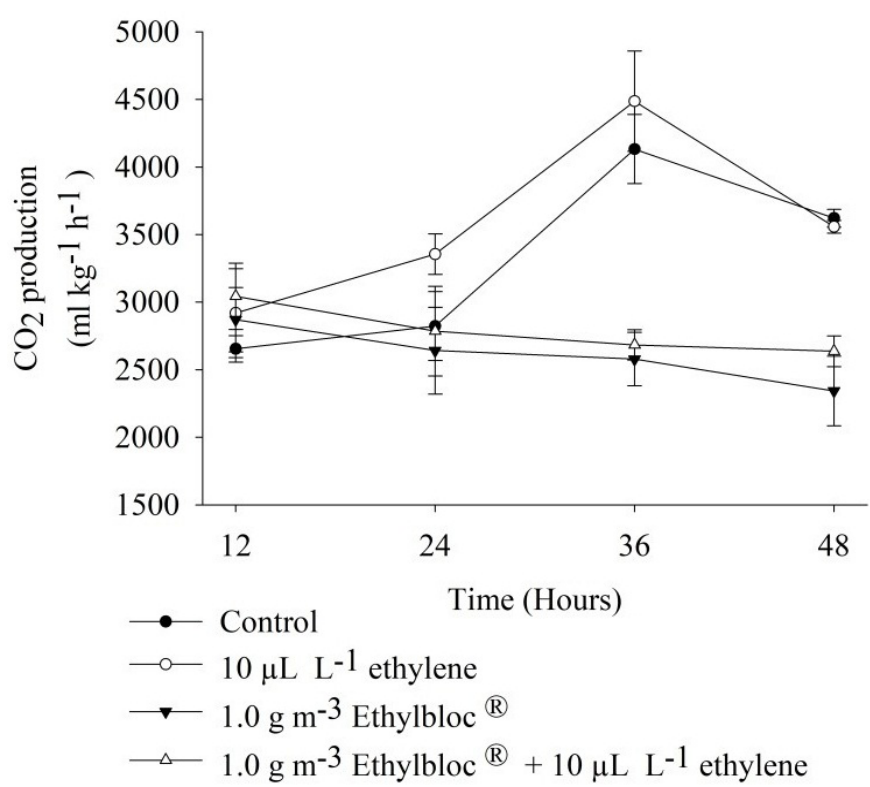

Figure 3. $\mathrm{CO}_{2}$ production of roses $\mathrm{cv}$. Osiana of the control, treated with $10 \mu \mathrm{L} \mathrm{L}^{-1}$ etileno; $1.0 \mathrm{gm}^{-1}$ Ethylbloc $^{\circledR}$ and $1.0 \mathrm{gm}^{-3}$ Ethylbloc $^{\circledR}+10 \mu \mathrm{L} \mathrm{L}^{-1}$ etileno by $24 \mathrm{~h}$. 
(Figure 4). The increase in the fresh mass is related to the increase in water absorption, suggesting that the application of Ethylbloc ${ }^{\circledR}$ increased the water absorption by the stems at the beginning of storage, which may be related to the effect of ethylene on lignification of the cell wall by increasing the activity of the phenylalanine ammonia lyase and peroxidase (Huang et al., 2013), which may restrict the uptake of water in cut flower.

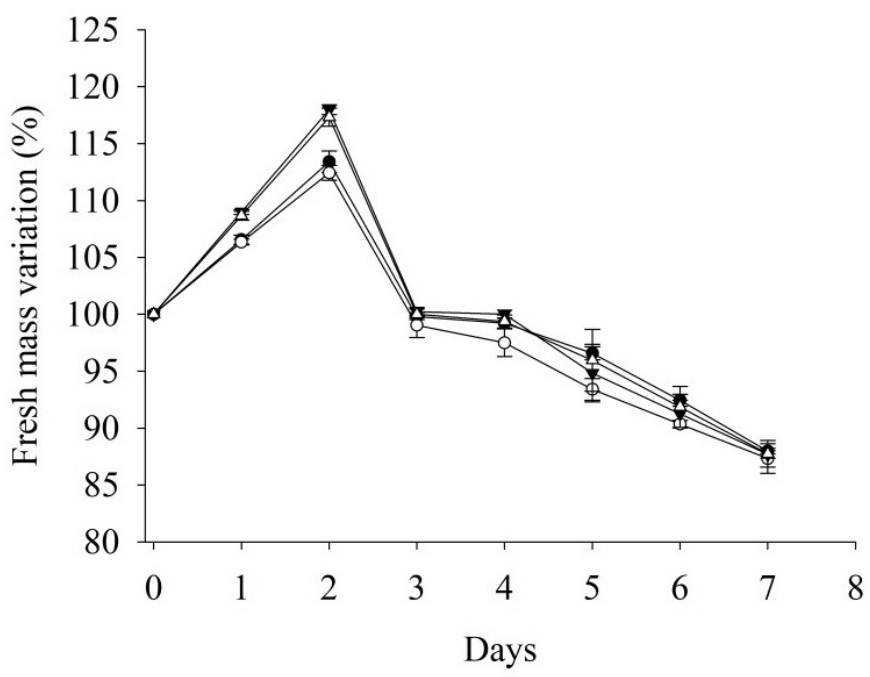

- Control

$\longrightarrow 10 \mu \mathrm{L} \mathrm{L}^{-1}$ ethylene

$\longrightarrow 1.0 \mathrm{gm}^{-3}$ Ethylbloc ${ }^{\circledR}$

$\triangle-1.0 \mathrm{gm}^{-3}$ Ethylbloc ${ }^{\circledR}+10 \mu \mathrm{L} \mathrm{L}^{-1}$ ethylene

Figure 4. Variation of fresh mass of roses cv. Osiana of the control, treated with $10 \mathrm{LL} \mathrm{L}^{-1}$ etileno; $1.0 \mathrm{gm}^{-1}$ Ethylbloc $^{\circledR}$ and $1.0 \mathrm{gm}^{-3}$ Ethylbloc $^{\circledR}+10 \mu \mathrm{L} \mathrm{L}^{-1}$ etileno by $24 \mathrm{~h}$.

\section{Conclusion}

The concentration of $1.0 \mathrm{~g} \mathrm{~m}^{3}$ of Ethylbloc ${ }^{\circledR}$ prolongs the vase life of $\mathrm{cv}$. Osiana stored at room temperature with the stems in water even in the presence of exogenous ethylene.

\section{Literature Cited}

Ali, M.; Nergi, D.; Ahmadi, N. Effects of 1-MCP and ethylene on postharvest quality and expression of senescence-associated genes in cut rose cv. Sparkle. Scientia Horticulturae, v.166, p.7883, 2014. https://doi.org/10.1016/j.scienta.2013.12.015.
Chang, Y. C. A.; Lin, W-L.; Hou, J-Y.; Yen, W-Y.; Lee, N. Concentration of 1-methylcyclopropene and the duration of its application affect antiethylene protection in Phalaenopsis. Scientia Horticulturae, v. 153, p. 117-123, 2013. https://doi.org/10.1016/j.scienta.2013.02.003.

Cheema, M. U. A.; Rees, D.; Colgan, R. J.; Taylor, M.; Westby, A. The effects of ethylene, 1-MCP and AVG on sprouting in sweetpotato roots. Postharvest Biology and Technology, v.85, p.89-93, 2013. https://doi.org/10.1016/j.postharvbio.2013.05.001.

Cordeiro, D. C.; Finger, F. L.; Santos, J. S.; Karsten, J.; Barbosa, J. G. Sensibilidade da rosa 'Osiana' ao etileno. Bragantia, v.70, n.3, p.677681, 2011. https://doi.org/10.1590/S0006-87052011000300025.

Finger, F. L.; Silva, T. P.; Araujo, F. F.; Barbosa, J. G. Postharvest quality of ornamental plants. In: Pareek, S. (Ed.). Postharvest ripening physiology of crops. Boca Raton: CRC Press, 2016. Chap. 3, p. 81-108.

Finger, L. F.; Silva, T. P.; Segatto, F. B.; Barbosa, J. G. Inhibition of ethylene response by 1-methylcyclopropene in potted ornamental pepper. Ciência Rural, v.45, n.6, p.964-969, 2015. https://doi.org/10.1590/0103-8478cr20131386.

Huang, W.; Liu, H.; Zhang, H.; Chen, Z.; Guo, Y.; Kang, Y. Ethyleneinduced changes in lignification and cell wall-degrading enzymes in the roots of mung bean (Vigna radiata) sprouts. Plant Physiology and Biochemistry, v.73, p.412-419, 2013. https://doi. org/10.1016/j.plaphy.2013.10.020.

In, B.-C.; Binder, B. M.; Falbel, T. G.; Patterson, S. E. Recovery of ethylene sensitivity and responses in carnation petals posttreatment with 1-methylcyclopropene. Postharvest Biology and Technology, v.121, p.78-86, 2016 https://doi.org/10.1016/j. postharvbio.2016.07.010.

In, B.-C.; Ha, S. T. T.; Leeb, Y. S.; Lima, J. H. Relationships between the longevity, water relations, ethylene sensitivity, and gene expression of cut roses. Postharvest Biology and Technology, v.131, p.74-83, 2017. https://doi.org/10.1016/j. postharvbio.2017.05.003.

Lima, P. C. C.; Ribeiro, W. S.; Oliveira, M. M. T.; Costa, L. C.; Finger, F. L. Ethylene, 1-methylcyclopropene and silver thiosulfate on the post-production of ornamental pepper. Ciência Rural, v.47, n.2, e20151611, 2017. https://doi.org/10.1590/0103-8478cr20151611.

Mapeli, A. M.; Finger, F. L.; Barbosa, J. G.; Barros, R. S.; Oliveira, L. S.; Segatto, F. B. Influence of storage temperature on Epidendrum ibaguense flowers. Acta Scientiarum. Agronomy, v.33, n.1, p.111115, 2011. https://doi.org/10.4025/actasciagron.v33i1.6365.

Silva, T. P.; Finger, F. L. Ethylene and 1-methylcyclopropene action over senescence of nasturtium flowers. Horticultura Brasileira, v. 33, n.4, p. 453-458, 2015. https://doi.org/10.1590/S0102053620150000400008. 